Geosistemy perehodnykh zon = Geosystems of Transition Zones / Геосистемы переходных зон

Content is available under the Creative Commons Attribution 4.0 International License (CC BY 4.0)

2021, vol. 5, No. 1, pp. 46-54

URL: http://journal.imgg.ru/archive.html ; https://elibrary.ru/title about.asp?id=64191

https://doi.org/10.30730/gtrz.2021.5.1.046-054

\title{
A geophysical pulse voltage generator for seismic and electric exploration of the subsurface
}

Ilia P. Dudchenko*, https://orcid.org/0000-0002-4967-7405, ilpadu@mail.ru

Dmitry V. Kostylev, https://orcid.org/0000-0002-8150-9575, d.kostylev@imgg.ru

Sergey A. Gulyakov, gulyakov97@mail.ru

Nikolay S. Stovbun, nikolay19972016@gmail.com

Institute of Marine Geology and Geophysics, FEB RAS, Yuzhno-Sakhalinsk, Russia

\section{Abstract PDF ENG Pезюме PDF RUS $\quad$ Full text $\underline{\text { PDF RUS }}$}

Abstract. This article describes the process and results of the development and testing of a cost-effective, portable, safe to move by air geophysical pulse voltage generator for seismic exploration of the subsurface. The generator is based on high-speed power electronic keys of a new generation consisting of an insulated gate bipolar transistor or a field-effect transistor based on silicon carbide, a compact power converter of alternating voltage from an autonomous generator or electric network to direct voltage using pulse-width modulation and current or voltage stabilization depending on the mode set by a researcher. Field tests were conducted to confirm the suitability of the developed design of the generator and the correctness of the chosen parameters of its elements. To this end, a detailed analysis of the effect of the developed geophysical generator on the parameters of the geoenvironment was carried out.

\section{Keywords:}

seismic exploration, electric exploration, geophysical research, insulated gate bipolar transistor, silicon carbide field-effect transistor, power converter, rectifier, seismic noise, electromagnetic sounding

For citation: Dudchenko I.P., Kostylev D.V., Gulya-kov S.A., Stovbun N.S. A geophysical pulse voltage generator for seismic and electric exploration of the subsurface. Geosistemy perehodnykh zon = Geosystems of Transition Zones, 2021, 5(1), pp. 46-54. (In Russ., abstr. in Engl.). https://doi.org/10.30730/gtrz.2021.5.1.046-054

Для цитирования: Дудченко И.П., Костылев Д.В., Гуляков С.А., Стовбун Н.С. Геофизический генератор импульсных напряжений для сейсмоэлектрической разведки недр. Геосистемы переходных зон, 2021, 5(1), c. 46-54. https://doi.org/10.30730/gtrz.2021.5.1.046-054

\section{References}

1. Voronin P.A. 2001. [Power semiconductor keys. Families, characteristics, and applications]. Moscow: Dodeka-XXI, 384 p. (In Russ.).

2. Zakupin A.S., Mubassarova V.A., Il'ichev P.V., Bogomolov L.M. 2014. Seismoacoustic responses to high-power electric pulses from well logging data at the Bishkek geodynamical test area. Izvestiya. Physics of the Solid Earth, 50(5): 692-706. https://doi.org/10.1134/s1069351314040193

3. Kostylev D.V., Boginskaya N.V. 2020. Seismoacoustic observations using molecular-electronic hydrophones on Sakhalin and the South Kuril Islands (Kunashir Island). Geosistemy perehodnykh zon = Geosystems of Transition Zones, 4(4): 486499. (In Russ.). https://doi.org/10.30730/gtrz.2020.4.4.486-499

4. Solovyov R.I., Morozov A.S. 2014. Overview of the PINBOARD 2 debugging complex and its practical application for developing devices on Atmel and ARM microcontrollers. In: Modern science through the eyes of young scientists: achievements, problems, prospects: Materials of the Interuniversity scientific and practical conf. Ryazan: Ryazan State Agrotechnological University named after P.A. Kostychev, p. 98-101. (In Russ.).

5. Yakubovskiy Yu.V., Renard I.V. 1991. [Electrical exploration]. Moscow: Nedra, 359 p. (In Russ.).

6. Kostylev D.V., Bogomolov L.M., Boginskaya N.V. 2019. About seismic observations on Sakhalin with the use of molecularelectronic seismic sensors of new type. IOP Conf. Series: Earth and Environmental Science, 324(012009). https://doi.org/10.1088/1755-1315/324/1/012009

7. Lyubushin A.A., Bobrovskiy V.S., Shopin S.A. 2016. Experience of complexation of global geophysical observations. Geodynamics \& Tectonophysics, 7(1): 191-195. 